\title{
Soldiers, Levellers and the "Middle Sort" in the English Revolution
}

\section{Ian Gentles}

Brian Manning, The English People and the English Revolution, 2nd edition (London: Bookmarks 1991)

Brian Manning, 1649: The Crisis of the English Revolution (London: Bookmarks 1992).

In both books under review Brian Manning presents again, unrevised and unrepentant, his thesis that the English revolution was in essence a class struggle led by the "middle sort" against the governing class of landowners, merchants, lawyers and higher clergy. The English People and the English Revolution is virtually identical to the first edition published in 1976, except that it now contains a wide-ranging, forty-seven-page introduction summarizing the work of other historians as it impinges upon Manning's thesis. The only significant change in the body of the text occurs in his passage on the function of puritanism in galvanizing the middle sort to overthrow the existing order. Originally it read " .... puritanism taught the middle sort of people to think for themselves and to assert their independence against King, lords and bishops. Godliness gave them status and the ability to express their identity as a separate class; and it enabled them to formulate and dignify their hostility towards the ruling class." In the second edition this passage is modified to read, “... puritanism taught some of the middle sort ..." (241, emphasis added)

Who were the "middle sort" on whom this revolution hinged? The author tells us that they included the landowning peasantry, copyholders beleaguered by high rents, insecurity of tenure, enclosure, population growth, bad harvests and industrial depression. The second major group who made up the middle sort were craftsmen, clothworkers particularly, who were devastated by the crises and slumps that were endemic in their industry after 1614 . Peasants and craftsmen shared a capacity for independent opinion and action which was rooted in their own economic independence. Other issues which united them were unjust taxation, tithes, and the limitations on the franchise.

It was bread-and-butter issues, led by the great depression in the cloth trade, that brought the lower classes into the revolution, Manning maintains. Once they became involved, "the nature of the crisis changed: economic questions advanced from the rear to the front of the stage, and the mere fact of the involvement of the people changed political conflicts and religious antagonisms into social conflicts and class antagonisms." (168) Yet earlier in the book Manning states that, in contrast to the 
nobility and gentry who focused on constitutional issues, it was "religious issues that stirred the mob" in London. (8) They feared popery, and hated the bishops and the prayer book. They were the ones behind the Root and Branch Petition for the radical restructuring of the church.

To reinforce his class interpretation of the revolution Manning points to the fact that in 1642-3 the people were more hostile towards cavalier soldiers than roundhead ones. He draws our attention to the activity of the middle sort on Parliament's behalf in Essex and Suffolk, as well as the clothing districts of Yorkshire and the West country, the lead-mining districts of the Somerset Mendips and the metal-working area of the West midlands. In Manchester and the West Riding of Yorkshire the lower classes pushed the gentry and stiffened their will to resist the king.

In his introduction to the second edition Manning sums up his interpretation as follows: "class conflict was always present but latent before 1640; it came close to the surface in 1641-2 and propelled parliament to challenge the King and the King to resist parliament; it drove parliament to victory, and became explicit in the aftermath of economic hardship and disillusionment with the result of victory: between 1646 and 1649 the revolution became an open class conflict with the emergence of the Levellers ..." (40)

Manning's interpretation is in some respects persuasive, and indeed it has won qualified support from historians as various as Tim Harris, Barry Reay, David Underdown, Derek Hirst, William Hunt, Keith Lindley, Clive Holmes, Ann Hughes and Gordon Blackwood. By contrast, John Morrill, Frances Dow, Anthony Fletcher and Buchanan Sharp have more or less rejected it out of hand. Derek Hirst has commented, "there does seem some correlation between industrial organization and popular alignment," whereas Buchanan Sharp denies that there was widespread popular support for parliament, commenting that "there is little solid evidence that the widespread outbreaks of popular disorder in 1641 and 1642 were in any sense motivated by pro-parliament sympathies or viewed with anything but suspicion by prominent parliamentarians." (24)

There are other problems with Manning's class interpretation. On one page he says that it was religion which drove on the London mob. A few pages later he states that it was bread and butter issues that brought the lower classes into the Civil War and transformed it into a class conflict. The notion that the lower classes pushed the gentry in Yorkshire to resist the king does not find support in a recent study of the northern parliamentary army. According to Jennifer Jones the officers of this army — both gentry and middle sort - far from being dragged reluctantly into the war, joined up voluntarily at great personal expense. Moreover, they dug deep into their own pockets to equip and arm their men, ran up huge arrears of pay, and also lent their men money when pay failed to arrive from the Treasury at Westminster. ${ }^{1}$ Although Manning acknowledges the reality of popular royalism, in that many freeholders, copyholders

1 Jennifer Jones, “The War in the North: The Northern Parliamentarian Army in the English Civil War, 1642-1645," Ph.D. thesis, York University [Toronto], 1991, 243, 248-50. 
and substantial farmers supported the king, he continues to deny that this support was freely given. Tenants were pressured by their landlords into joining the king's army. What is more, "fear and force lay in the background if loyalty and deference failed." (325) It is a pity that Manning has left this sentence unmodified when in the introduction he acknowledges that Underdown's researches "confirm the existence of a widespread popular royalism ... which cannot be dismissed as the mere product of deferential obedience to the élite." (29) Certainly in my own work on London I have found that by the summer of 1647 , if not before, large numbers of lower class people - apprentices, butchers, porters, sailors and watermen in particular - were vehement in their hostility to the Independent Party and in their support for peace with the king. ${ }^{2}$

Likewise, it seems to me that Manning misinterprets the clubmen phenomenon when he classifies them as "lower class men showing the way to win the war, and as portents of a popular triumph over the royalists." (311) The clubmen were a chameleon-like group whose agenda differed from county to county. The glue which bound them together was localism, and a hatred of the Civil War. In every part of the country their overriding objective was to keep the war out of their own county. In some counties the best way to realize this objective might be to back the Parliamentary forces. But in other counties they backed the royalists. Cromwell and Fairfax, who physically crushed an armed assembly of Dorset, Wiltshire and Somerset clubmen in the summer of 1645 , would have been surprised to learn that these men were "portents of a popular triumph over the royalists." (311)

1649: The Crisis of the English Revolution is a more synthetic but less coherent book than The English People. It rehearses many of the same themes found in the first book, but resembles more a series of discrete essays than a connected account of this crucial year in the history of the revolution. One of the book's chief virtues is that it engages, in a spirited but fair-minded fashion, with most of the recent scholarly work on the English revolution, by writers such as Christopher Hill, David Underdown, Gerald Aylmer, John Morrill, Perez Zagorin, Ronald Hutton, and the present writer. In response to his critics Manning has somewhat modified his earlier analysis. Accepting Underdown's point that the revolutionary agenda was forced through by a minority of religious radicals, he none the less makes the telling point that the King was hardly an object of great popular veneration. During the year or more that he was in captivity not one of his subjects risked his life to save him.

In this apocalyptic year the air was thick with prophecies of the second coming of Jesus Christ. This expectant millenarianism, observes Manning, "gave people strength and courage to do extraordinary and revolutionary things, and the capacity to visualise a new form of government and a different sort of society, in the conviction that they were pursuing God's purpose; but that same expectation meant that whatever they put in place of what they destroyed had only a provisional and transitory

2 Ian Gentles, The New Model Army in England, Ireland and Scotland, 1645-1653 (Oxford 1992), 187, 256. 


\section{4 left history}

character, until Christ inaugurated his kingdom on earth. If that did not happen soon the dreams of real and permanent change would quickly fade." (47)

The second chapter is an excursion into the recent scholarship on status and class in early-modern England. Manning is compelled to confront the fact that historians as diverse as Lawrence Stone, Peter Laslett, Keith Wrightson and David Cressy deny the existence of social class in this period. Lawrence Stone's statement is as good as any: English society was "a single hierarchy of status defined by titular rank, and to a certain extent by legal and fiscal privilege." (quoted on 49) Manning is adept at pointing out the inconsistencies between the accounts of these other scholars, but he is less successful at convincing us to adopt his model of a self-conscious "middle sort" who piloted the revolution. His assertion that "... the shift of power was from a class - the governing class of peers and greater or county gentry. It was a shift of power towards the area of status uncertainty where minor gentry, yeomen, business and professional men merged" is more nuanced than what we find in the first book, but inevitably it blurs the limpid clarity of his earlier thesis. (68-9) Thus it is strange to read that "the social context of the revolution was an evolving middle class and working class." (78)

The greatest inconsistency however occurs in the third chapter, on "The revolution and the poor." He opens the chapter with a quotation from J.H. Elliott that "There was one permanent and universal precondition for revolt in every society in early modern Europe: the pressure of population on food resources, and the ever-present threat of harvest failure and starvation. Because of this threat, the possibility of popular uprisings was built into every society, and only a sudden tax increase or a rise in the price of bread was needed to precipitate a tumult." (79) This precondition was without question present in England between 1646 and 1649. The conjuncture of harvest failures and trade depression in those years made it, in JP Cooper's words, "... probably the worst economic crisis of the century." (79) Yet after describing the impact of this economic crisis in the most heart-rending terms, Manning is compelled to admit that "the most remarkable fact is the absence of popular disorders." (95) This does not prevent him from reiterating that "the basic conflict in society was between rich and poor." (103) Yet the great heroes of Manning's book, the Diggers, always maintained that their ideal of agrarian communism must be brought to pass by voluntary action, not violence. Manning makes the novel point however, that the Diggers did favour the withdrawal of labour from the estates of landlords, and the stoppage of rent payments by tenants. If not violent, these strategies would certainly have been coercive.

Gerrard Winstanley, the leader of the Diggers, is an enormously attractive figure, even if he did revert to a life of respectability after the Restoration, as J.D. Alsop has shown. ${ }^{3}$ But their story has been well told before, by Christopher Hill in particular, and one wonders why it should be necessary to devote so many pages to a tiny movement which attracted no support from the army or the Levellers. Nor is one

3 "Gerrard Winstanley's later life," Past \& Present, 82 (1979), 73-81 
entirely satisfied with Manning's explanation for the absence of any rising of the poor during the revolutionary period. It is all very well to write that "the poor were contained within a structure of dependency and domination." (133) So were the continental poor, but that did not prevent them from rising up against their oppressors several times during the sixteenth and seventeenth centuries.

The fourth chapter, like the second, is a wide-ranging consideration of a question that has animated social historians over the past two decades: gender and patriarchalism. Disappointing to most feminists must be the fact that even at the height of the revolution England remained patriarchal and gerontocratic. Great advances were made in the realms of religious toleration, lay preaching, and the spiritual equality of men and women, but no one, not even female radicals, questioned the assumption that the husband should be the head of the household. The number of women who joined the radical sects was small, and as Manning himself points out, the first politically active women were anti-revolutionary. The peace movement of 1642 and 1643, which produced several petitions and demonstrations in Westminster against the civil war, was led by women. Parliament dispersed them by armed force. Despite the moderation of their message, these women were radical "in asserting a feminine political consciousness and a feminine voice and a feminine presence in the masculine preserve of national politics and political decision making. "(152) In 1649 Leveller women, in the face of much hostility and ridicule, demonstrated at the door of the House of Commons for the liberation of John Lilburne. Yet there is no evidence that these radical women, who asserted that they too were made in the image of Christ, ever demanded the vote. Like everyone else, they accepted the patriarchal assumption that they were represented by their husbands. As Manning wryly observes, "It is odd ... to have expected the Levellers and Diggers to have advocated votes for women when two centuries later the Chartists still did not do so." (165)

The most important chapter of the book is the last, entitled "Soldiers, levellers and revolution." Besides an exhaustive treatment of the pamphlet and newsbook literature of the time, the author engages with the writings of contemporary scholars, notably Barbara Taft, Austin Woolrych, Murray Tolmie, John Morrill and the present writer. Manning finds wanting the argument of Taft and myself that the Officers' version of the Agreement of the People got nowhere in the House of Commons because it had been imposed on the senior officers by the junior officers. He believes that its failure had more to do with the army's essentially undemocratic view of itself as a godly elite, an instrument in the hands of the almighty. This was a different outlook from that of the Levellers; hence Manning accuses me of making a misleading assertion when I state that both officers and Levellers would have established something like a "dictatorship of the godly." My argument was that by excluding from the franchise all those who had opposed the revolution, or who refused to sign the Agreement, the Levellers were in effect greatly narrowing the definition of "the people." 4 Manning retorts that "however broadly or narrowly the Levellers defined 'the people,' they did 
not make 'godliness' a qualification for exercising the franchise or holding office." (176) This is a fair point.

Elsewhere however, Manning is less persuasive. In his chapter on the poor he tells us that in their joint opposition to free quarter, the interests of the army coincided with those of the people. This masked a much more fundamental discord between the two, for by 1646 the people were heartily sick of taxation that was heavier than anything the king had ever imposed. Yet the excise and the monthly assessment, so vociferously denounced by the Levellers, were the army's lifeblood, and the only guarantee against a royalist revival. To his credit, Manning recognizes this fundamental disharmony between the Levellers and the army in this last chapter. At the same time however, he is loth to accept my finding that only a minority of the men in three (not four as Manning alleges) of the troops of Ireton's regiment joined the Levellerinspired mutiny at Burford. This finding is based on a careful review of all the printed and manuscript sources, ${ }^{5}$ but Manning provides no references to support his statement that "the evidence does not support the assertion of Gentles." (203, $267 \mathrm{n} ., 87)$ This disagreement points to a persistent methodological problem in Manning's work: his nearly exclusive reliance on printed tracts and newsbooks, and his refusal to consult unpublished archival sources. In an earlier review John Morrill made the valid point that much of the printed material produced by the revolution was mere propaganda, and therefore has to be handled with the greatest care. ${ }^{6}$

Concerning the mutinous regiments that were crushed at Burford in May 1649, Manning comments that it would be misleading to call it a "Leveller revolt."(208) After all the mutineers did not mention the recently published Agreement of the People in their printed declarations, nor the Leveller leaders who were at that moment languishing in prison. On the other hand their demand for the reinstatement of the General Council of the Army was one which the Levellers had been making since March. Significant too is the fact that printed and manuscript sources at the time refer repeatedly to "the Leveller rising." as a defeat for the Levellers, as Manning himself acknowledges. In any case, Manning and $I$ are in agreement that the mutinies at Burford, Banbury and Wellingborough in the spring of 1649 were a watershed, marking the triumph of military force over the more radical and populist wing of the revolution.

Both books are unfortunately marred by a structural defect: each lacks a conclusion. Instead of tying together the themes and arguments presented in the previous chapters, the books either simply trail off with a mocking quotation from Richard Overton in the case of 1649 , or end abruptly with the failure of the Levellers in the case of The English People.

To tie together the themes of this review, Manning's unabashed reassertion of the reality of class conflict as the engine behind the English Revolution will win the assent

Ibid., 334, nn. 89-92.

"Provincial squires and 'middling sorts' in the Great Rebellion," Historical Journal, 20 (1977), 230.

The New Model A rmy, 536, n. 120. 
Soldiers, Levellers and the "Middle Sort" 117

of few experts in the field. On the other hand, his wide reading in the printed sources, and his courteous manner of debating those with whom he disagrees, command our admiration. There is much stimulation, and much to ponder on in both books. 